\title{
Relationship Between Growth and Unemployment in Petroleum Exporting Countries: Case of Congo
}

\author{
Idrys Fransmel Okombi \\ Faculty of Economics' sciences, Marien Ngouabi University, Congo-Brazzaville \\ E-mail: idrysfransmel@gmail.com
}

Received: August 8, 2018; Accepted: January 1, 2019; Published: March 31, 2019

Permalink/DOI: http://dx.doi.org/10.17977/um002v11i12019p014

\begin{abstract}
The purpose of this article is to examine relation between growth and unemployment in Congo. To this, the error correction model ARDL is used. The estimation results show the existence of relation significantly negative between growth and long term unemployment on the period 1991.Q12016.Q1. Such a result accounts an unemployment existence of a structural character in Congo. In this regard, the resolution of unemployment problem in Congo goes through the policies of the offer. In other words, the Congolese government must put in place policies aiming to increase productivity of production factors. To be specific, the government can favor the augmentation of a prospective GDP, urging companies with important manpower to invest, by an increase of productive public investment.
\end{abstract}

Keywords: Growth, Employment, ARDL, Congo

JEL Classification: C32; E23, E24, 055

\section{INTRODUCTION}

A high economic growth and weak unemployment are part of the four objectives of the economic policy. However, these two objectives of economic policy are interdependent according to the Law of Okun (1962). In fact, this law brings to the fore a cimetric relation between growth and unemployment, occasioning unemployment-growth dilemma. Unemployment rises when the effective GDP goes out of its prospective level. For this purpose, unemployment has a contra cyclic character, which suggests that to remedy unemployment problem, the government has to act on global demand. Though relation between growth and unemployment are well comprised to a short term (Okun, 1962), it's not the same to a long term. For this purpose, the long term relation sign between growth and unemployment is undetermined. In such a context, it appears to be opportune for this article to bring elements of information on empirical basis.

The problematic related to young people unemployment in Africa seems relevant for at least three reasons. First, brain drain, insecurity and poverty are byproducts of unemployment. Then, it could also be a source of social and political unrest. In accordance with the second point, the Arab spring of 2011 is a perfect example. Finally, many Africans risk their lives to reach Europe, this is also one of the dynamics linked to young people unemployment. Since then, to remedy different social problems that scourge Africa, the promotion of creative growth of employment is necessary. 
Though a high growth level is a remedy to unemployment problem, it isn't less only in Africa, important growth levels are not translated by unemployment reduction. In fact, the recent economic growth was not translated by corresponding progression of employment and the few many job creations have been essentially observed on the informal sector. So many factors might explain this state of fact. First, the offset between training offers (teachings taught) and skills most wanted by employers. According to EY (2015), professional and technical skills are those that would be most in demand in all sectors in Africa. Second, extractive industries that are the basis of growth in these countries, use a high intensity capitalistic production technique. They are furthermore, relatively isolated to the rest of the economy. Therefore, one of the characteristics of the African economies is the weak diversification of their production basis.

Being an empirical origin, Okun law is a good example of success of statistical induction, where observation precedes theory. It is in fact the inverse relation between growth and unemployment, observed by Okun (1962) on the American economy that efforts have been put into place in order to give a much better theoretical underpinning to this relation. Okun shows that when the actual GDP is inferior to $3 \%$ to the prospective GDP, unemployment rate is superior to 1 point to its normal rate. If the Okun gap is $6 \%$, unemployment is superior to 2 points to its normal rate. An employment point is associated to a gap of 3\%. This proportionality relation is acceptable in the case of American economy of the 1950s and 1960s, may take different values in other contexts. Furthermore, this law may even be questioned in some economies in which production is done on the basis of a production technique a high intensity capital.

Many works based on linear relation in African countries have invalidated the existence of symmetric relation between growth and unemployment (Moosa, 2008, Bankole and Fatai, 2013; Babalola and Saka, 2013; Moroke, 2014; Alhdiy and al., 2015). However, works completed in some African countries validate the inverse relation between growth and unemployment (Furceri, 2012; Makaringe et Khobai, 2018; Phiri, 2014). Moosa (2008) proceeds to the verification of the Okun law in North Africa (Algeria, Egypt, Morocco and Tunisia) on the period 19902005. By using co-integration approach, study results show that Okun law is not applicable for two reasons: inadequacy between work offer and demand, work market stiffness and public sector's prevalence, hydrocarbon and mining. Furceri proceeds to the verification of the Okun law in Algeria for the period 1980-2008 from regression in statistical panel (Least Squares) and dynamic (GMM). Study results validate Okun law but with a weak coefficient (-0.05). By using quarterly data on a period stretching from 1990-2014, Bouaziz and Andari (2015) validate Okun law in Tunisia from co-integration analysis with -0.7 coefficient.

Bankole and Fatai (2013) have studied relation between growth and unemployment in Nigeria from annual data from 1980-2012. The use of the correction error model with estimation objectives, enlightens the inapplicability of the Okun law in Nigeria. The results of Bankole and Fatai are relatively close to those of Moroke (2014). He (Moroke) examines the applicability of the Okun law in South Africa from quarterly data of the period 1990-2013 and uses the correction error model. Estimation results show that relation between growth and unemployment is significantly positive, which questions the inverse relation between growth and unemployment in South Africa. By resorting to ARDL 
approach on the period 1980-2013, Udude and Nnachi (2017) also reveal the inapplicability of Okun law in Nigeria.

On the other hand, the existence of a negative relation between growth and unemployment is verified whether in long or short term in the works of Makaringe and Khobai (2018). This study aimed at studying the impact of unemployment on economic growth in South Africa through quarterly data on the period stretching from 1994-2016. By using ADRL model, the estimation results suggest that there exists long term relation between economic growth and unemployment. Empirical results have confirmed that there exists a negative relation between economic growth and unemployment in long and short term. The existence of an inverse relation between growth and unemployment in long term is not unprecedented in economic literature. Phiri (2014) had already found such a result in the case of South Africa, based on the cointegration approach, and over a period from 2000 to 2013. The results of the study show that in the long run there is a significantly negative relationship between growth and unemployment. However, Alhdiy et al. (2015), based on the cointegration approach, and the quarterly data for the period 2006-2013, reveal the absence of the long-run relationship between growth and unemployment in Egypt.

Apart from studies having enlightened the tie between market of goods and services and work market from relation between growth and unemployment, a study based on Congo focused on relation between employment and economic growth (Ndinga, 2013). The latter uses the correction error model on the period 1968-2011, and show that there exists long term relation which is positive and significant between growth and unemployment in Congo. This result is confirmed in filigree, the existence of an inverse relation between unemployment and long term economic growth in Congo.

As regard works developed above, the applicability of the Okun law is questioned in Sub-Saharan Africa. A plausible explanation to this observation may be tied to strong contribution of the primary sector in the GDP, reflecting a weak diversification of most economies. To this, it is legitimate to add the weak efficiency on work markets. In such a context, the existence of a structural unemployment seems to be one of the common characteristics of Sub-Saharan African countries' economies.

In such a context, one can estimate that unemployment that characterizes African economies is structural. Taking as a basis Congo, country member of Central Africa Monetary and Economic Community, petroleum exporting country, the analysis of the relation between unemployment and growth raise the question of the existence of the inverse relation between two long term variables. The validation of such a relation accounts what unemployment and productivity have to deal with simultaneously in order to hope an improvement of macroeconomic performances of the Congolese economy. The purpose of this article is to empirically verify the existence of a symmetric relation between growth and unemployment in Congo.

\section{METHOD}

\section{Model specification}

This study has adopted Okun model type (1962). However, it is legitimate to underline that there are two specification classes of Okun law: the gap and the 
first difference model. Basing on Okun model, we bring a change by considering unemployment as an independent variable, whereas economic growth represented by actual GDP as dependent variable. Since then, the writing model permitting to determine relation between growth and unemployment may be represented as the following:

$$
\operatorname{LPIBR}_{t}=\beta_{0}+\beta_{1} L C H O_{t}+\varepsilon_{t}
$$

Or PIBR means actual GDP, CHO symbolizes unemployment and L means logarithm. Elasticity calculated indicates variation in percentage (respectively percentage points) of actual GDP because of $1 \%$ unemployment variation. Such a specification is close to that of Makaringe end Khobai (2018), in their study of long term impact of employment on growth in South Africa. If applicable, except the key explanatory variable, such as unemployment, two control variables, oil price and inflation can be taken into account. So, we are going with estimation objectives, use the following equation:

$$
L P I B R_{t}=\beta_{0}+\beta_{1} L C H O_{t}+\beta_{2} L P P E T R_{t}+L I P C_{t}+\varepsilon_{t}
$$

From equation 2, Okun coefficient (CO) may be like this: $C O=\frac{1}{\beta_{1}}$.

Economic growth measure as a variable describing the evolution of wealth creating process within a nation was done through the evolution of its rate. Explanatory variables approved in the model are respectively unemployment, oil price and inflation. Oil price is taken into account because the petroleum section plays a major role in the GDP. However, the expected indication of its relation with growth is negative, because of the vulnerability of economies of petroleum exporting countries to external chocks (oil price fluctuation). Furthermore, in view of the fact that a minimum inflation is necessary growth, it is taken into account through a proxy variable, price index to consumption (IPC). So, one has to expect inflation influence on growth to be positive.

\section{Data Source}

Data used are of secondary type and are relative to the period 1991-2016, or 26 observations. They have been compiled on the World Bank official web sites (WID, 2016). It's all about unemployment variables, actual GDP, oil price and inflation rate. Furthermore, it should be first noted that all variables have undergone a smoothing by logarithm introduction. Second, annual data have transformed into quarterly data (1991.Q1-2016.Q1). In this regard, the quarterly method of collected annual data (Denton, 1971), mostly used by IMF economists has been approved. In fact, it is important to acknowledge that econometric rests on a certain number of relatively binding conditions but necessary for the validation of estimation results.

\section{RESULT AND DISCUSSION}

Before estimating short and long term coefficients, we are going to determine the integration order of variables.

\section{Variables' Stationarity Test}

In this case, we use the Dickey and Fuller test (1981), done on explained variable and the four explanatory selected variables have brought about results presented in the following chart $\mathrm{N}^{\circ} 1$.

Table 1. Variables Integration Order 


\begin{tabular}{lllll}
\hline Variable & LPIBR & LCHO & LPPETR & LIPC \\
\hline Integration order & $\mathrm{I}(1)$ & $\mathrm{I}(0)$ & $\mathrm{I}(1)$ & $\mathrm{I}(0)$ \\
\hline Source: Eviews & & & &
\end{tabular}

A remarkable fact spring from these tests of unitary root: explained variable (LPIBR) is I (1) whereas explanatory variables are either I (1), or I (1). So, ARDL model application is well appropriate for this article. Before applying this model, it is important to determine the optimal lag.

\section{Optimal Number of Delays}

An important step in the case of dynamic models is the determination of the optimum number of delays. To do so, different criteria are often used, most common are: Akaike information criterion (AIC) and Schwartz information criterion (SIC). If applicable, the test indicates from criteria LR, FPE, AIC, and SIC, the existence of an optimal delay equal to 2 . So, the number of delay 2 is approved.

\section{Table 2. Identification of optimal offset}

VAR Lag Order Selection Criteria

Endogenous variables: LPIBR LCHO LPPETR LIPC

Exogenous variables: $\mathrm{C}$

Sample: 1991Q1 2016Q4

Included observations: 93

\begin{tabular}{ccccccc} 
Lag & LogL & LR & FPE & AIC & SC & HQ \\
\hline 0 & 112.5615 & NA & $1.14 \mathrm{e}-06$ & -2.334655 & -2.225726 & -2.290673 \\
\hline 1 & 925.8732 & 1539.171 & $4.07 \mathrm{e}-14$ & -19.48114 & -18.93650 & -19.26123 \\
\hline 2 & 1045.100 & 215.3770 & $4.43 \mathrm{e}-15^{*}$ & $-21.70107^{*}$ & $-20.72071^{*}$ & $-21.30523^{*}$ \\
\hline 3 & 1048.323 & 5.545952 & $5.86 \mathrm{e}-15$ & -21.42631 & -20.01023 & -20.85454 \\
\hline 4 & 1054.932 & 10.80072 & $7.24 \mathrm{e}-15$ & -21.22434 & -19.37254 & -20.47664 \\
\hline 5 & 1070.388 & 23.93170 & $7.44 \mathrm{e}-15$ & -21.21264 & -18.92513 & -20.28901 \\
\hline 6 & 1094.391 & $35.10107^{*}$ & $6.40 \mathrm{e}-15$ & -21.38474 & -18.66152 & -20.28518 \\
\hline 7 & 1098.647 & 5.858008 & $8.51 \mathrm{e}-15$ & -21.13219 & -17.97325 & -19.85670 \\
\hline 8 & 1105.929 & 9.396709 & $1.07 \mathrm{e}-14$ & -20.94471 & -17.35006 & -19.49329
\end{tabular}

* indicates lag order selected by the criterion

LR: sequential modified LR test statistic (each test at 5\% level)

FPE: Final prediction error

AIC: Akaike information criterion

SC: Schwarz information criterion

HQ: Hannan-Quinn information criterion

Source : author from Eviews

\section{ARDL Model Estimation}

To examine relationships between consumption (LPIBR) and explanatory variables, the study resort to co-integration approach based on autoregressive models with a stepped delay (ARDL : Auto Regressive Distributed Lag) developed by Parasan and Shin (1995, 1999), Parasan and al. (1996), and Parasan (1997). In fact, traditional co-integration approach (Engle and Granger, 1987; Johansen, 1988) to determine the existence of a long term relation between variables presents serious bounds: necessary to have integrated series of the same order I (0) or I (1) and lacks 
power towards samples of small size. Co-integration approach proposed by Parasan, Shin, and Smith and based on ARDL model, allows to solve these bounds. This approach allows to test long term relationships between variables I (0) and I (1) and provides strong estimations long and short term relationships for samples of small size centered under 80 observations (Narayan, 2005). That's how we get the following ARDL specification:

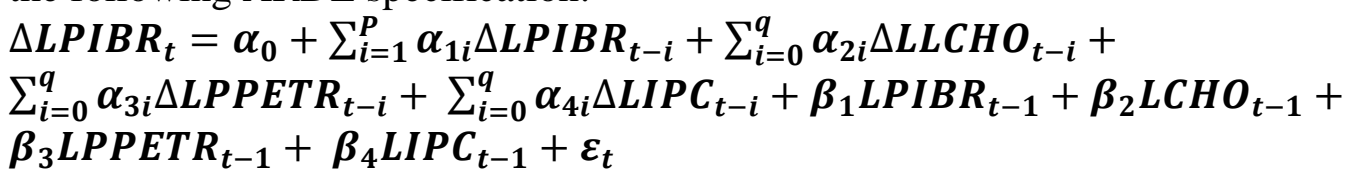

$\Delta$ : operator of first difference $; \alpha_{0}$ : constant $; \alpha_{1} \ldots \alpha_{4}$ : short term effects $; \beta_{1} \ldots \beta_{4}$ : long term dynamic of model ; $\varepsilon \sim$ iid $(0, \sigma)$ : error term (white noise).

As regard the application of ARDL model, it is important to estimate an ARDL model ( $p, q)$ which will serve as a bound test manner, which, in turn will confirm or disconfirm co-integration relationship in long term. Basing on delays' criteria selection, ARDL model has been estimated with a maximum of 2 delays for all variables. Chart 3 shows that all coefficients of ARDL model $(1,1)$ are significant (Prob $<5 \%$ and even 1\% in the great majority of cases). Likewise, the model is totally significant, Prob. (F-statistic). The R-square of 0,999 show that 99, $9 \%$ variations of checking account balance are explained by significant variables of the model. Moreover, all variables are significant.

Table 3. ARDL model results $(1,1)$

\begin{tabular}{ccccc}
\hline \multicolumn{5}{c}{ Variable Indépendante: LPIBR } \\
\hline Variable & Coefficient & Std. Error & t-Statistic & Prob. ${ }^{*}$ \\
\hline LPIBR(-1) & 1.619813 & 0.077082 & 21.01407 & 0.0000 \\
\hline LPIBR(-2) & -0.638296 & 0.075169 & -8.491506 & 0.0000 \\
\hline LCHO & -0.177401 & 0.087505 & -2.027334 & 0.0456 \\
\hline LPPETR & -0.005664 & 0.001856 & -3.051225 & 0.0030 \\
\hline LIPC & -0.195714 & 0.049717 & -3.936549 & 0.0002 \\
\hline LIPC(-1) & 0.348586 & 0.092131 & 3.783604 & 0.0003 \\
\hline LIPC(-2) & -0.147728 & 0.049567 & -2.980400 & 0.0037 \\
\hline C & 0.381612 & 0.125206 & 3.047879 & 0.0030 \\
\hline R-squared & 0.999681 & & & \\
Adjusted R-squared & 0.999656 & & & \\
F-statistic & 40732.95 & Durbin-Watson stat & 1.896522 \\
Prob(F-statistic) & 0.000000 & & & \\
\hline Sol-e:
\end{tabular}

Source: author from Eview

Bounds Test

The primary objective of this test is to enlighten on the existence or the nonexistence of long term relationship between variables. For this purpose, the results of chart 4 show that the value of $F=8.182$ over exceeds those of superior bounds of critical values to $5 \%$. For this purpose, zero hypothesis is rejected from the absence of a long term relationship and to conclude on the existence of a long term relationship between variables.

Table 4. test bounds results 


\begin{tabular}{|c|c|c|c|}
\hline Significance & I0 Bound & I1 Bound & \\
\hline $10 \%$ & 2.37 & 3.2 & \multirow{4}{*}{$\begin{array}{l}\text { F-statistic: } \\
8.182099\end{array}$} \\
\hline $5 \%$ & 2.79 & 3.67 & \\
\hline $2.5 \%$ & 3.15 & 4.08 & \\
\hline $1 \%$ & 3.65 & 4.66 & \\
\hline
\end{tabular}

Source: author from Eviews

\section{Long Term Coefficient and Short Term Dynamic}

Table 5 short and long term coefficients' results of estimation

\begin{tabular}{|c|c|c|c|}
\hline \multicolumn{4}{|c|}{ Variable dépendante: $\triangle$ LPIBR } \\
\hline Variable & Coefficient & t-Statistic & Prob. \\
\hline$\Delta \mathrm{LCHO}$ & 0.012665 & 0.974780 & 0.3323 \\
\hline$\triangle \mathrm{LPPETR}$ & 0.003503 & 0.466150 & 0.6422 \\
\hline$\Delta \mathrm{LIPC}$ & -0.198394 & -4.345836 & 0.0000 \\
\hline$\Delta \mathrm{LIPC}(-1)$ & 0.147381 & 3.086706 & 0.0027 \\
\hline CointEq(-1) & -0.019323 & -4.084979 & 0.0001 \\
\hline Variable & Coefficient & t-Statistic & Prob. \\
\hline
\end{tabular}

Variable dépendante: LPIBR

\begin{tabular}{crrr}
\hline Variables & Coefficient & t-Statistic & Prob \\
\hline LCHO & -4.099505 & -2.328804 & 0.0221 \\
\hline LPPETR & -0.306421 & -4.273593 & 0.0000 \\
\hline LIPC & 0.278294 & 1.926895 & 0.0571 \\
\hline C & 20.646056 & 22.827445 & 0.0000
\end{tabular}

Source: author from Eviews

The test results' bounds have demonstrated that there is exist a long term relationship between two variables which is confirmed by the correction error model. In fact, we find, as expected, an adjustment coefficient that is negative $(-0$. 0193 ) between 0 and -1 and strongly significant (probability $=0.0001$ ) The results of estimations are of good quality. In fact, the diagnostic tests in terms of errors (see appendix) shows that the probability linked to Jacque Bera statistic is equal to 0, 393 superior to 5\%, normality hypothesis of variables is accepted. In other words, there's $39,3 \%$ chance to make a bad a decision. In addition, ARCH test shows that the probability of «Obs*R-squared » is equal to 0.9861 , superior to 5\%, zero hypothesis of homoscedasticity of residues is accepted. The White test also corroborates homoscedasticity hypothesis of errors, for the y relative is equal to 0 . 1883 , superior to $5 \%$. «Obs*R-squared» probability tied to Breusch-PaganGodfrey reveals that there's no correlation of errors. Finally, stability tests of the model of cu sum and cu sum squared show that the model is structurally and punctually stable.

The results of our estimations show that relationship between growth and unemployment is not significant in short term. On the other hand, relationship between growth and unemployment in long term in negative. Hypothesis of symmetric relationship between growth and unemployment is verified. This result is not unprecedented in economic literature. In fact, such a result had already been found in the works Phiri (2014), Makaringe and Khobai (2018) in the verification of a long term relationship between growth and unemployment in South Africa. Our results suggest that to improve the performances of the Congolese economy, productivity and unemployment must be addressed simultaneously. So, this result 
enlightens on the character of structural unemployment in Congo, which can result from the inadequacy of trainings as compared to job offers in work market. Another plausible explanation to the existence of a structural unemployment in Congo may be due to the important contribution of the petroleum sector to the GDP. However, it should be noted that the petroleum sector uses a production technique of high capitalistic intensity. In such a context, the solution to the unemployment problem that prevails in Congo goes through policies that favor prospective GDP growth.

Oil price has a negative contribution to growth. In fact, oil price increase of 1 point brings about a decrease of economic growth to 0.31 point to actual GDP. The effect on inflation on economic growth is differentiated. In fact, in a short term, inflation on growth has a negative effect on economic growth. However, in long term, the impact of inflation on growth is significantly negative. Short term result can be justified by the fact that an important inflation level reduces the purchasing power of households, which reduces households' consumption and at the same time GDP. As for long term result, it is justified by the fact that minimum inflation is necessary for economic growth. This state of fact is corroborated by the Fisher relationship who supports that an augmentation of inflation reduces actual interest rate, which in turn increases private investment, as a result economic growth.

\section{CONCLUSION}

The purpose of our article was to empirically verify the link between unemployment and economic growth. To do this, the correction error ARDL model was estimated. The results of our estimations reveal that there is no relationship between growth and unemployment in long term. However, in long term, the results of our estimations confirmed the existence of an inverse relationship between economic growth and unemployment which proves the existence of structural unemployment in Congo. In this regard, the implementation of policies of demand, in other words, policies that aim at regulating macroeconomic fluctuation are weak in order to solve unemployment problem in Congo. The best way to solve unemployment problem in Congo goes through policies of offer which comprise, strengthening work productivity by leading education towards professional training. Furthermore, the government can give preference to increasing prospective GDP, by urging investments of companies generating employment, by increasing productive public expenditures.

\section{REFERENCES}

Alhdiy F. M., Johari, F., Daud, S. N. M., \& Rahman, A. A. (2015). Short and Long Term Relationship Between Economic Growth and Unemployment in Egypt: An Empirical Analysis. Mediterranean Journal of Social Sciences, 6(4), 454-462.

Babalola S. J., Saka J. O., \& Adenuga I. A. (2013). The Validity of Okun's Law in Nigeria: A Difference Model Approach. Asian Economic and Financial Review, 3(12), 1598-1608

Bankole A. S., \& Fatai B. O. (2013). Empirical Test of Okun's Law in Nigeria Test Empirique de la loi d'Okun au Nigeria. International Journal of Economic Practices and Theories, 3(3), 227-231.

Andari, C. E., \& Bouaziz, R. (2015). Is the Okun's Law Valid in Tunisia?. MPRA Paper No. 67998. 
Denton, F. T. (1971). Adjustment of Monthly or Quarterly Series to Annual Totals: An Approach based on Quadratic Minimization. Journal of the American Statistical Association, 66(333), 99-102.

Dickey, D. A., and Fuller, W. A. (1981), "Likelihood ratio statistics for autoregressive time series with a unitroot", Econometrica, 49(4), 10571072.

Engle, R. F., and Granger, C. W. (1987), "Co-integration and error correction: Representation, estimation, and testing", Econometrica, 55(2), 251-276.

EY (2015). EY's Attractiveness Survey: Africa 2015 - Making Choices.

Furceri D. (2012), "Unemployment and Labor Market Issues in Algeria", Modélisation en output-gap. Régression en panel statique (MCO) et dynamique (GMM), International Monetary Fund.

Gordon, R. J. (1984). Unemployment and potential output in the 1980s. Brookings Papers on Economic Activity , 2, 538-540.

Johansen, S (1988), "Statistical Analysis of Cointegration Vectors", Journal of Economic Dynamics and Control, Vol. 12, pp. 231.54.

Leshoro T.L.A. (2014), "Empirical Analysis of Employment Elasticity of Growth in Botswana", Mediterranean Journal of Social Sciences MCSER Publishing, Rome-Italy, Vol 5 No 2, P.171-179.

Makaringe S.C. and Khobai H. (2018), "The effect of unemployment on economic growth in South Africa (1994-2016)", MPRA Paper No. 85305, posted 20 March 2018 05:33 UTC.

Meyer D.F. (2017), "an analysis of the short and long-run effects of economic growth on employment in South Africa", International Journal of Economics and Finance Studies, Vol 9, No 1, P. 177-193.

Moosa, I. (2008). Economic growth and unemployment in Arab countries: Is Okun's Law valid? Proceedings of the international conference on the unemployment crises in the Arab Countries. March 17 to 18. Cairo, Egypt.

Moroke N. (2014), “An Empirical Robustness of Okun's Law in South Africa: An Error Correction Modelling approach", Mediterranean Journal of Social Sciences, Vol 5 No 23, P435-443.

Ndinga (2013), «Marché du travail et marché des biens dans les pays pétroliers d'Afrique centrale : le cas du Congo », Revue d'Economie Appliquée, vol. 1, N¹, P. 71-95.

Okun, A. M. (1962). Potential GNP: Its measurement and significance. American Statistical Association , 98 -103. Reprinted from the 1962 proceedings of the Business and Economic Statistics Association.

Pesaran, H.M. , Shin, Y. et Smith, R. (1996), "Testing the Existence of a long-run relationship", DEA Working Paper Series N 9622,Department of Applied Economics, University of Cambridge.

Pesaran, H.M. et Shin, Y. (1995), "Autorgressive Distributed Lag Modelling Approach to Cointegration Analysis", DEA Working Paper Series N 9514 , Department of Applied Economics, University of Cambridge.

Pesaran, H.M. et Shin, Y. (1999), "Autorgressive Distributed Lag Modelling Approach to Cointegration Analysis, Chapter 11, in Storm, S. (ed), Econometrics and Econmic theory in the 20th Century: The Ragnar Frisch Centennial Symposium", Cambridge University Press. Cambridge. 
Pesaran, M. H., \& Shin, Y., 1997, An autoregressive distributed lag modeling approach to cointegration analysis. England: University of Cambridge.

Phiri A. (2014), "Re-evaluating Okun's law in South Africa: A nonlinear cointegration approach", MPRA Paper No. 57398, posted 18. July 2014 08:55 UTC.

Udude C.C and Nnachi D.N. (2017), "Testing the Validity of Okun's Law in Nigeria: An Autoregressive Distributed Lag Approach (1980-2013)", World Applied Sciences Journal 35 (5): 754-766. 


\section{Appendix}

\section{Appendix 1: stationarity tests' results}

\begin{tabular}{|c|c|c|c|c|}
\hline \multirow[b]{2}{*}{ Variables } & \multicolumn{3}{|c|}{ ADF Test } & \multirow[b]{2}{*}{$\begin{array}{c}\text { integration } \\
\text { Order }\end{array}$} \\
\hline & $\begin{array}{c}\text { ADF } \\
\text { Statistic in } \\
\text { level }\end{array}$ & $\begin{array}{c}\text { Statistic in } \\
1 \text { st } \\
\text { difference }\end{array}$ & $\begin{array}{c}\text { Critical } \\
\text { value of } \\
\text { Mckinon }\end{array}$ & \\
\hline LPIBR & 0.074738 & -3.357363 & -2.890926 & $\mathbf{I}(\mathbf{1})$ \\
\hline LCHO & -2.974180 & - & -2.892200 & $\mathbf{I}(\mathbf{0})$ \\
\hline LPPETR & -1.506623 & -3.663031 & -2.890926 & I(1) \\
\hline LIPC & -2.990999 & - & -2.990999 & $\mathbf{I}(\mathbf{0})$ \\
\hline
\end{tabular}

Source : author from Eviews

\section{Appendix 2: Estimation Result ARDL model}

Dependent Variable: LPIBR

Method: ARDL

Sample (adjusted): 1991Q3 2016Q1

Included observations: 99 after adjustments

Maximum dependent lags: 2 (Automatic selection)

Model selection method: Akaike info criterion (AIC)

Dynamic regressors (2 lags, automatic): LCHO LPPETR LIPC

Fixed regressors: $\mathrm{C}$

Number of models evalulated: 54

Selected Model: ARDL(2, 0, 0, 2)

\begin{tabular}{crrrr}
\hline \hline Variable & Coefficient & Std. Error & t-Statistic & Prob. \\
\hline \hline LPIBR(-1) & 1.619813 & 0.077082 & 21.01407 & 0.0000 \\
LPIBR(-2) & -0.638296 & 0.075169 & -8.491506 & 0.0000 \\
LCHO & -0.177401 & 0.087505 & -2.027334 & 0.0456 \\
LPPETR & -0.005664 & 0.001856 & -3.051225 & 0.0030 \\
LIPC & -0.195714 & 0.049717 & -3.936549 & 0.0002 \\
LIPC(-1) & 0.348586 & 0.092131 & 3.783604 & 0.0003 \\
LIPC(-2) & -0.147728 & 0.049567 & -2.980400 & 0.0037 \\
C & 0.381612 & 0.125206 & 3.047879 & 0.0030 \\
\hline \hline R-squared & 0.999681 & Mean dependent var & 22.94224 \\
Adjusted R-squared & 0.999656 & S.D. dependent var & 0.265197 \\
S.E. of regression & 0.004916 & Akaike info criterion & -7.715386 \\
Sum squared resid & 0.002199 & Schwarz criterion & -7.505679 \\
Log likelihood & 389.9116 & Hannan-Quinn criter. & -7.630538 \\
F-statistic & 40732.95 & Durbin-Watson stat & 1.896522 \\
Prob(F-statistic) & 0.000000 & & \\
\hline \hline
\end{tabular}

*Note: $p$-values and any subsequent tests do not account for model selection.

Source : author from Eviews

\section{Appendix 3: Test Bounds results}

ARDL Bounds Test

Sample: 1991Q3 2016Q1

Included observations: 99 
Null Hypothesis: No long-run relationships exist

\begin{tabular}{lll}
\hline \hline Test Statistic & Value & $\mathrm{k}$ \\
\hline \hline F-statistic & 8.182099 & 3 \\
\hline \hline
\end{tabular}

Critical Value Bounds

\begin{tabular}{lcc}
\hline \hline Significance & I0 Bound & I1 Bound \\
\hline \hline $10 \%$ & 2.37 & 3.2 \\
$5 \%$ & 2.79 & 3.67 \\
$2.5 \%$ & 3.15 & 4.08 \\
$1 \%$ & 3.65 & 4.66 \\
\hline \hline
\end{tabular}

Source : author from Eviews

\section{Appendix 4: Short and long term coefficient results}

ARDL Cointegrating And Long Run Form

Dependent Variable: LPIBR

Selected Model: ARDL(2, 0, 0, 2)

Sample: 1991Q1 2016Q4

Included observations: 99

\begin{tabular}{|c|c|c|c|c|}
\hline \multicolumn{5}{|c|}{ Cointegrating Form } \\
\hline Variable & Coefficient & Std. Error & t-Statistic & Prob. \\
\hline $\mathrm{D}(\mathrm{LPIBR}(-1))$ & 0.631343 & 0.071787 & 8.794644 & 0.0000 \\
\hline $\mathrm{D}(\mathrm{LCHO})$ & 0.012665 & 0.012993 & 0.974780 & 0.3323 \\
\hline D(LPPETR) & 0.003503 & 0.007515 & 0.466150 & 0.6422 \\
\hline $\mathrm{D}(\mathrm{LIPC})$ & -0.198394 & 0.045652 & -4.345836 & 0.0000 \\
\hline $\mathrm{D}(\operatorname{LIPC}(-1))$ & 0.147381 & 0.047747 & 3.086706 & 0.0027 \\
\hline CointEq(-1) & -0.019323 & 0.004730 & -4.084979 & 0.0001 \\
\hline \multicolumn{5}{|c|}{$\begin{array}{l}\text { Cointeq }=\text { LPIBR }-\left(-0.009950^{\star} \text { LCHO }-0.3064^{\star} \text { LPPETR + 0.2783*LIPC + }\right. \\
20.6461)\end{array}$} \\
\hline \multicolumn{5}{|c|}{ Long Run Coefficients } \\
\hline Variable & Coefficient & Std. Error & t-Statistic & Prob. \\
\hline LCHO & -0.009950 & 0.042728 & -2.328804 & 0.0221 \\
\hline LPPETR & -0.306421 & 0.071701 & -4.273593 & 0.0000 \\
\hline LIPC & 0.278294 & 0.144426 & 1.926895 & 0.0571 \\
\hline C & 20.646056 & 0.904440 & 22.827445 & 0.0000 \\
\hline
\end{tabular}

Source : author from Eviews

\section{Appendix 5: Test result of model validity}

Breusch-Godfrey Serial Correlation LM Test:

F-statistic

2.126246 Prob. F(2,89)

0.1253 
Heteroskedasticity Test: Breusch-Pagan-Godfrey

\begin{tabular}{llll}
\hline \hline F-statistic & 1.390751 & Prob. F(7,91) & 0.2188 \\
Obs*R-squared & 9.567561 & Prob. Chi-Square(7) & 0.2144 \\
Scaled explained SS & 25.04910 & Prob. Chi-Square(7) & 0.0007 \\
\hline \hline
\end{tabular}

Heteroskedasticity Test: ARCH

\begin{tabular}{llll}
\hline \hline F-statistic & 0.000297 & Prob. F(1,96) & 0.9863 \\
Obs*R-squared & 0.000303 & Prob. Chi-Square(1) & 0.9861 \\
\hline \hline
\end{tabular}

Heteroskedasticity Test: White

\begin{tabular}{llll}
\hline F-statistic & 1.461433 & Prob. F(7,91) & 0.1910 \\
Obs*R-squared & 10.00467 & Prob. Chi-Square(7) & 0.1883 \\
Scaled explained SS & 26.19350 & Prob. Chi-Square(7) & 0.0005 \\
\hline \hline
\end{tabular}

Ramsey RESET Test

Equation: UNTITLED

Specification: LPIBR LPIBR(-1) LPIBR(-2) LCHO LPPETR LIPC LIPC(-1) LIPC(-2) C

Omitted Variables: Squares of fitted values

\begin{tabular}{lccc}
\hline \hline & Value & df & Probability \\
\cline { 2 - 4 } t-statistic & 1.903365 & 90 & 0.0602 \\
F-statistic & 3.622798 & $(1,90)$ & 0.0602 \\
\hline \hline F-test summary: & & & \\
& & & Mean \\
Test SSR & Sum of Sq. & df & Squares \\
\cline { 2 - 4 } Restricted SSR & $8.51 \mathrm{E}-05$ & 1 & $8.51 \mathrm{E}-05$ \\
Unrestricted SSR & 0.002199 & 91 & $2.42 \mathrm{E}-05$ \\
\hline \hline
\end{tabular}


Okombi I.F. / Jurnal Ekonomi dan Studi Pembangunan, 11 (1), 2019, 14 - 27
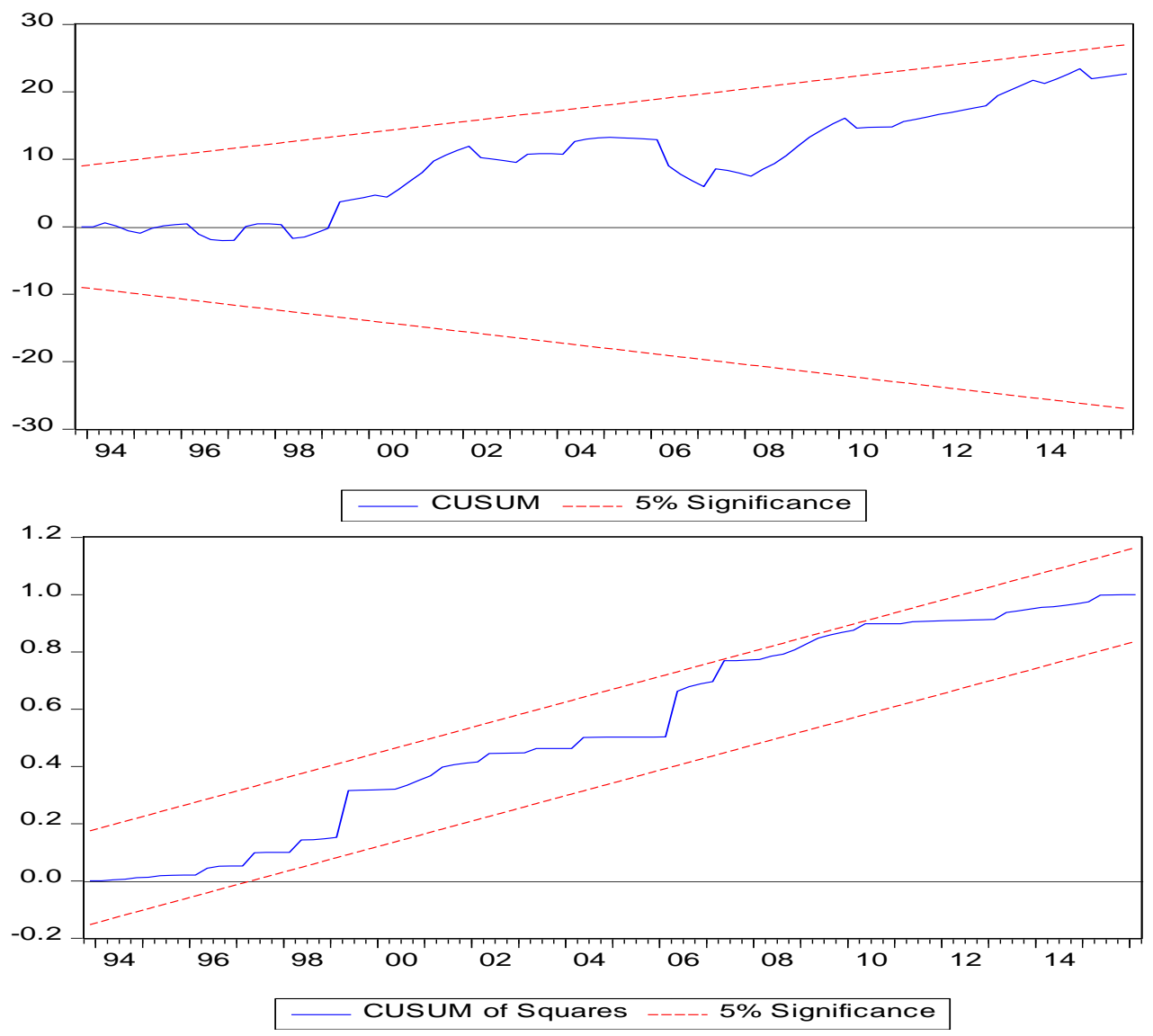